\title{
Cytogenetic Analysis of Barrett's Mucosa and Adenocarcinoma of the Distal Esophagus and Cardia
}

\author{
Marian B. E. Menke-Pluymers, Ellen van Drunen, Kees J. Vissers, \\ Andries H. Mulder, Hugo W. Tilanus, and Anna Hagemeijer
}

\begin{abstract}
We performed flow cytometry and cytogenetic analysis of 37 adenocarcinomas of the distal esophagus and cardia, of which 22 arose in Barrett's mucosa. Two of eight analyzed specimens of Barrett's mucosa had clonal chromosomal abnormalities. In 19 cases clonal chromosomal abnormalities were found in tumor tissue. The complex pattern of cytogenetic changes did not differ among the adenocarcinomas arisen in Barrett's esophagus, and those in the distal esophagus without Barrett's mucosa or cardia. Abnormal karyotypes with multiple and complex rearrangements were seen in 11 cases and with single or a few numeric changes in eight. Losses of chromosomes 4,18, 21, and $Y$ were the most frequent numeric changes. Loss of the $Y$ chromosome was observed in eight of 26 tumors of males (31\%). Gairs of chromosomes 14 and 20 were also frequent numeric changes. Structural abnormalities were observed in 13 of the abnormal karyotypes ( $68 \%$ ). The chromosome arms most frequently rearranged were $1 p, 3 q, 11 p$ and $22 p$. The chromosome arm most frequently contributing to losses was $1 p$, with the shortest region of overlap being 1p22-33. The chromosome arms most often involved in gains were $11 p$ and $22 p$, and $i(3 q)$ was the isochromosome that was most frequently identified.
\end{abstract}

\section{INTRODUCTION}

There has been a striking increase in the incidence of adenocarcinoma of the esophagus and the esophagogastric junction in North Americá and Western Europe in recent years $[1,2]$. Most esophageal and gastroesophageal adenocarcinomas appear to arise from Barrett's esophagus [3]. As a consequence of persistent damage, the squamous epithelial lining of the esophagus is replaced by columnar epithelium. The risk of developing an adenocarcinoma in Barrett's esophagus is at least 30-125 times that expected for a similar population without Barrett's esophagus [4]. Barrett's adenocarcinoma occurs as a result of progression of severe dysplastic changes in the abnormal mucosal lining of the esophagus, involving a series of genetic alterations in the cells that comprise the Barrett's epithelium [5]. A better understanding of the underlying mechanisms of carcinogenesis in Barrett's esophagus and the discovery of markers identifying the subset of patients at high risk would be of great importance. The correlation between

From the Departments of Surgery (M. B. E. M.-P., H. W. T.), Pathology (K. J. V., A. H. M.), and Clinical Genetics (E. V. D., A. H.), University Hospital Rotterdam-Dijkzigt, Rotterdam, The Netherlands.

Address reprint requests to: Dr. M. B. E. Menke-Pluymers, Department of Surgery, University Hospital Rotterdam-Dijkzigt, Dr. Molewaterplein 40, 3015 GD Rotterdam, The Netherlands.

Received December 21, 1995; accepted March 6, 1996. dysplastic changes and aneuploidy has been demonstrated by flow cytometric (FCM) techniques $[5,6]$. A few studies demonstrated clonal chromosome abnormalities in Barrett's epithelium and adenocarcinoma [7-10]. The karyotypes were often complex, but loss of the $\mathrm{Y}$ chromosome was a frequent finding. Genetic changes affecting $3 q$ and the $11 \mathrm{p} 13-15$ region have been described in esophageal adenocarcinomas as well as in gastric cancer $[8,9]$. However, since the cytogenetic study of solid tumors and premalignant tissues is difficult, there are no large series reported.

We report cytogenetic studies of 37 adenocarcinomas of the distal esophagus and cardia of which the majority $(59 \%)$ arose in Barrett's mucosa. In these cases $(n=22)$ cytogenetic analysis was also performed on Barrett's epithelium.

\section{MATERIALS AND METHODS}

\section{Patients}

Patients with an esophageal carcinoma were referred to the Rotterdam Esophageal Tumor Study Group for evaluation and treatment. Three groups were investigated: 1) patients with an adenocarcinoma in Barrett's esophagus; 2) patients with an adenocarcinoma in the distal esophagus without Barrett's mucosa; and 3) patients with an adenocarcinoma of the cardia. All patients underwent an esophagectomy without preoperative radiotherapy or che- 
motherapy, and were included in the study during the period November 1989 to August 1992. Tissue specimens of 37 patients (26 male and 11 female; mean age of 62 years) were analyzed by histopathologic, FCM, and cytogenetic methods.

\section{Pathology}

Based on histopathologic findings and site of the tumor, the 37 adenocarcinomas of the patients were divided into three subgroups:

1. Adenocarcinoma in Barrett's esophagus, if the bulk of the tumor was located in the distal esophagus and columnar epithelium was found proximal to the tumor at microscopic examination $(n=22)$.

2. Adenocarcinoma in the distal esophagus, if the bulk of the tumor was located in the distal esophagus and no columnar epithelium could be demonstrated proximal to the tumor by microscopic examination $(n=10)$.

3. Adenocarcinoma of the cardia, if the bulk of the tumor was located in the cardia with tumor growth into the distal esophagus $(n=5)$.

From all 37 resection specimens fresh tissue samples of the esophageal mucosa and the tumor were taken out and divided into three parts. One part of every tissue sample was used for histopathologic analysis, one for cytogenetic analysis, and a third part was stored in liquid nitrogen $\left(-70^{\circ} \mathrm{C}\right)$ for $\mathrm{FCM}$. In a few cases tissue samples were taken from lymph node metastases.

If columnar epithelium was found, specimens were designated as no dysplasia, mild-, moderate-, and severe dysplasia according to criteria for epithelial dysplasia in the stomach as described by Morson et al. [11]. In all tumor specimens adenocarcinoma was found and the differentiation grade of the tumor was determined.
Table 1 Clinical and histopathologic characteristics of 22 patients with an adenocarcinoma in Barrett's esophagus

\begin{tabular}{|c|c|c|c|c|c|c|}
\hline \multirow{3}{*}{$\begin{array}{l}\text { Patient } \\
\text { no. }\end{array}$} & \multirow[b]{3}{*}{ Sex } & \multirow[b]{3}{*}{ Age } & \multirow{2}{*}{\multicolumn{2}{|c|}{ Adenocarcinoma $^{a}$}} & \multicolumn{2}{|c|}{$\operatorname{Mucosa}^{a}$} \\
\hline & & & & & \multirow[b]{2}{*}{ Type } & \multirow{2}{*}{$\begin{array}{l}\text { Grade of } \\
\text { dysplasia }\end{array}$} \\
\hline & & & pTNM & Grade $^{b}$ & & \\
\hline 1 & $\mathrm{~F}$ & 76 & T3N1M0 & G1 & & \\
\hline 3 & M & 61 & T1N0M0 & G3 & & \\
\hline 5 & M & 58 & T3N1M0 & G2 & Squamous & \\
\hline 9 & M & 45 & T2N0MO & G3 & Barrett & Mild \\
\hline 11 & M & 63 & T1N0M0 & G3 & Barrett & Mild \\
\hline 12 & $\mathrm{~F}$ & 65 & T3N1M0 & G3 & & \\
\hline 13 & M & 59 & T3N1M0 & G3 & Squamous & \\
\hline 17 & M & 80 & T1N0M0 & $\mathrm{G} 2$ & Barrett & Moderate \\
\hline 18 & $\mathrm{M}$ & 67 & T3N1M0 & G3 & & \\
\hline 19 & M & 69 & T3N1M0 & $\mathrm{G} 3^{d}$ & Barrett & No \\
\hline 20 & $\mathrm{~F}$ & 67 & T3N1M1 & G3 & Barrett & Moderate \\
\hline 23 & $\mathrm{~F}$ & 77 & T3N0M0 & G2 & Barrett & No \\
\hline 24 & $\mathrm{~F}$ & 68 & T1N0M0 & $\mathrm{G} 2$ & Barrett & Severe \\
\hline 25 & $\mathrm{~F}$ & 75 & T1N0M0 & G2 & Barrett & Mild \\
\hline 26 & $\mathrm{~F}$ & 67 & T3N1M1 & G3 & & \\
\hline 27 & M & 77 & T3N1M0 & G3 & Barrett & $\mathrm{No}$ \\
\hline 29 & M & 70 & T2NoMo & $\mathrm{G} 2$ & Barrett & Mild \\
\hline 31 & M & 53 & T3N1M0 & G2 & Squamous & \\
\hline 32 & $\mathrm{~F}$ & 64 & T2NoMo & G1 & Barrett & No \\
\hline 36 & $\mathrm{~F}$ & 73 & T3N1M1 & $\mathrm{G} 2$ & Barrett & Moderate \\
\hline 38 & M & 50 & T3N1M0 & G3 & & \\
\hline 39 & M & 70 & T3NOMO & G3 & & \\
\hline
\end{tabular}

${ }^{a}$ Histopathologic diagnosis of tissue samples for flow cytometric and cytogenetic analysis.

${ }^{b}$ Differentiation grade: $G 1$ = well differentiated: $G 2=$ moderately differentiated; $G 3$ = poorly differentiated.

"Histologic diagnosis of mucosa specimens on which cytogenetic and flow cytometric analysis were performed.

"Tissue sample from a lymph node metastasis.

Table 2 Flow cytometric and cytogenetic analysis of Barrett's mucosa

\begin{tabular}{|c|c|c|c|c|c|c|}
\hline \multirow[b]{2}{*}{$\begin{array}{l}\text { Patient } \\
\text { no. }\end{array}$} & \multirow[b]{2}{*}{$\begin{array}{l}\text { Flowcytometry } \\
\text { (DNA indices) }\end{array}$} & \multicolumn{5}{|c|}{ Number of metaphases analyzed } \\
\hline & & Total & Normal & $\begin{array}{l}\text { Abnormal } \\
\text { nonclonal }\end{array}$ & $\begin{array}{l}\text { Abnormal } \\
\text { clonal }\end{array}$ & Karyotype of clonal abnormality \\
\hline 9 & Aneuploid $(1.93,3.43)$ & & & & & \\
\hline 11 & Diploid & 1 & & 1 & & \\
\hline 17 & Diploid & 16 & 7 & 4 & 5 & $45(34-46), X,-Y[c p 5]$ \\
\hline 19 & Diploid & 26 & 20 & 6 & & \\
\hline 20 & Tetraploid & 6 & 4 & 2 & & \\
\hline 23 & Diploid & 2 & 2 & & & \\
\hline 24 & Aneuploid $(1.18,2.32)$ & 3 & 2 & 1 & & \\
\hline 25 & Aneuploid (1.61) & 5 & & & $1+4^{a}$ & $\begin{array}{l}72<3 n>, X X X,+3,-4,-5,-5,-6,+8,+\operatorname{add}(9)(p 22),+\operatorname{del} l \\
(10)(q 23),-11,+12,-14, \operatorname{add}(15)(\mathrm{p} 12),+\operatorname{add}(15)(\mathrm{q} 21), \\
\text { add }(17)(\mathrm{p} 12),-18,+\operatorname{add}(19)(\mathrm{q} 13),+20,-21,+22, \\
\quad+\operatorname{mar} 1,+\operatorname{mar} 2[\mathrm{cp} 4]\end{array}$ \\
\hline 27 & Diploid & 1 & 1 & & & \\
\hline 29 & Diploid & & & & & \\
\hline 32 & Diploid & & & & & \\
\hline 36 & Diploid & & & & & \\
\hline
\end{tabular}

"Indicates metaphases that were counted, with markers identified, but which could not be completely karyotyped. 


\section{FCM}

Fresh tissue samples for FCM were immediately deep-frozen and stored in liquid nitrogen $\left(-70^{\circ}\right)$. These specimens were prepared for FCM according to the method described in Vindelov et al. [12]. The nuclear suspension was filtered through a $40-\mu \mathrm{m}$ mesh filter and stained with pro- pidium iodide (Sigma Chemical Co., St. Louis, MO). Cellular DNA content of at least 10,000 cells was measured on FACS scan (Beckton Dickinson, Mountain View, CA). The data were fed into a Data General computer. Aneuploidy was determined both by visual inspection of the histograms and confirmation of an aneuploid population

Table 3 Flowcytometric and cytogenetic analysis of adenocarcinoma in Barrett's esophagus

\begin{tabular}{|c|c|c|c|c|c|c|}
\hline \multirow[b]{2}{*}{$\begin{array}{l}\text { Patient } \\
\text { no. }\end{array}$} & \multirow[b]{2}{*}{$\begin{array}{l}\text { Flowcytometry } \\
\text { (DNA indices) }\end{array}$} & \multicolumn{5}{|c|}{ No. of metaphases analyzed } \\
\hline & & Total & Normal & $\begin{array}{l}\text { Abnormal } \\
\text { nonclonal }\end{array}$ & $\begin{array}{l}\text { Abnormal } \\
\text { clonal }\end{array}$ & Karyotype of clonal abnormality \\
\hline 1 & & 10 & & & $6+4^{a}$ & $\begin{array}{l}39-42<2 \mathrm{n}>, \mathrm{X},-\mathrm{X},+3,-4, \text { add(10)(q26), }+ \text { hsr }(11) \\
(\mathrm{p} 14),-13,-17,-18,-20,-21, \text { add(22)(p11), }+ \text { mar, }, \\
\text { dmin[cp10] }\end{array}$ \\
\hline 3 & & 1 & 1 & & & \\
\hline 5 & & 14 & 9 & 2 & $1+2^{a}$ & 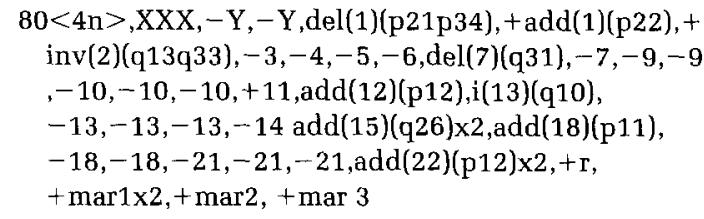 \\
\hline 9 & Aneuploid $(1.85,3.29)$ & 9 & 6 & 3 & & \\
\hline 11 & Tetraploid & 6 & 4 & 2 & & \\
\hline 12 & Aneuploid (1.65) & 20 & 16 & 2 & 2 & $46-47, \mathrm{XX},+2 \operatorname{mar}[\mathrm{cp} 2]$ \\
\hline 13 & Diploid & 28 & 3 & & $8+7^{a}$ & $\begin{array}{l}37-42<2 \mathrm{n}>, \mathrm{X}, \mathrm{i}(\mathrm{Y})(\mathrm{q} 10), \operatorname{del}(1)(\mathrm{p} 21 \mathrm{p} 34),+\operatorname{add}(3)(\mathrm{q} 27) \\
-5, \mathrm{i}(7)(\mathrm{p} 10), \operatorname{add}(8)(\mathrm{q} 24),-9,-11,-12,-13 \mathrm{i}(13) \\
(\mathrm{q} 10),-15,-19,-20,-22, \operatorname{add}(22)(\mathrm{q} 13),+\mathrm{r},+\operatorname{mar} \\
{[\mathrm{cp} 15]}\end{array}$ \\
\hline & & & & & $7+3^{\circ}$ & $\begin{array}{l}69(64-83)<3 n>, X X, i(Y)(q 10),+2,+3,+\operatorname{add}(3)(q 27) \\
\quad+4,-5,+\operatorname{add}(6)(q 26) \times 2, i(7)(p 10),+\mathrm{i}(7)(p 10), \operatorname{add}(8) \\
(q 24) \times 2,-10,-11,-12, \mathrm{i}(13)(\mathrm{q} 10) \times 2,+14,+15,-17 \\
\quad-18,-19,-20,+21, \operatorname{add}(22)(\mathrm{q} 13) \times 2,+\mathrm{r} \times 2,+\operatorname{mar} \\
{[\mathrm{cp} 10]}\end{array}$ \\
\hline 17 & Aneuploid (1.56) & 34 & 12 & 6 & 16 & $45(34-45), X,-Y[10],-10,-14,-17,-18,-21[\operatorname{cp} 16]$ \\
\hline 18 & Aneuploid (1.49) & 37 & 17 & 2 & 18 & $\begin{array}{l}45(36-47), X,-Y[9],-2,-6,-7,-9,-11,-18,-19 \\
\quad-22[\operatorname{cp} 18]\end{array}$ \\
\hline 19 & Aneuploid $(1.50,2.05)$ & 11 & 5 & 2 & 4 & $66-69<3 n>, X,-Y$, add(9)(p22), +mar[cp4] \\
\hline 20 & Diploid & 8 & 6 & 2 & & \\
\hline 23 & Aneuploid $(1.98,2.93)$ & 12 & 9 & 3 & & \\
\hline 24 & Aneuploid $(1.20,2.43)$ & 6 & 4 & 2 & & \\
\hline 25 & Aneuploid (1.61) & 6 & & & $4+2^{a}$ & $\begin{array}{l}63-71<3 \mathrm{n}>, \mathrm{XXX},+\mathrm{X}, \operatorname{del}(1)(\mathrm{p} 21 \mathrm{p} 33),+3,-4,-5,+8, \\
\text { add(9)(p22),+10,-13,+14,add(15)(p12),add(15) } \\
(\mathrm{q} 21),-18,+\operatorname{add}(19)(\mathrm{q} 13), \operatorname{add}(21)(\mathrm{p} 21),+22,+\operatorname{mar} 1, \\
\quad+\operatorname{mar} 2[\mathrm{cp} 6]\end{array}$ \\
\hline 26 & Aneuploid $(1.47,1.78)$ & 4 & 4 & & & \\
\hline 27 & Aneuploid $(1.49,2.07)$ & & & & & \\
\hline 29 & Aneuploid (1.69) & 8 & 6 & 2 & & \\
\hline 31 & Aneuploid (1.42) & 7 & 1 & 2 & $2+2^{a}$ & $\begin{array}{l}51-55<2 n>, X, \operatorname{add}(Y)(p 13),+\operatorname{del}(1)(\mathrm{p} 22),+\operatorname{del}(2) \\
(\mathrm{p} 15),+\operatorname{add}(3)(\mathrm{p} 26),+\operatorname{del}(3)(\mathrm{q} 24),+9,+11,+ \text { add } \\
(14)(\mathrm{q} 32), \mathrm{hsr}(14)(\mathrm{p} 11), \mathrm{i}(17)(\mathrm{p} 10) \times 2, \operatorname{add}(18)(\mathrm{p} 11) \\
\quad+20,+20,-21,-22,-22,+\operatorname{mar}[\mathrm{cp} 4]\end{array}$ \\
\hline 32 & Aneuploid $(1.99,2.79)$ & 3 & 2 & 1 & & \\
\hline 36 & Aneuploid (1.72) & 8 & & & $5+3^{a}$ & 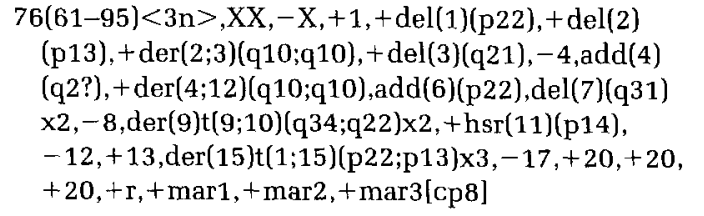 \\
\hline 38 & & 1 & 1 & & & \\
\hline 39 & & 23 & 10 & 8 & 5 & $39-45<2 n>, X Y,-19,-21[\mathrm{cp} 5]$ \\
\hline
\end{tabular}

${ }^{a}$ Indicates metaphases that were counted, with markers identified, but which could not be completely karyotyped. 
Table 4 Clinical and histopathologic characteristics of patients with an adenocarcinoma in the distal esophagus without Barrett's mucosa (DO) or cardia $(\mathrm{C})$

\begin{tabular}{|c|c|c|c|c|c|}
\hline \multirow{2}{*}{$\begin{array}{l}\text { Patient } \\
\text { no. }\end{array}$} & \multirow[b]{2}{*}{ Sex } & \multirow[b]{2}{*}{ Age } & \multicolumn{3}{|c|}{ Adenocarcinoma } \\
\hline & & & pTNM & Grade $^{n}$ & Localization \\
\hline 2 & M & 44 & T3N1M1 & G3 & Do \\
\hline 6 & M & 68 & T3N1M0 & $\mathrm{G} 2$ & Do \\
\hline 7 & M & 46 & & $G 2^{b}$ & Do \\
\hline 8 & M & 44 & & $\mathrm{G} 2^{h}$ & Do \\
\hline 10 & $\mathrm{~F}$ & 62 & T3N1M0 & G3 & Do \\
\hline 16 & M & 63 & T2N1M1 & G3 & Do \\
\hline 28 & M & 44 & T2NoMo & $\mathrm{G} 2$ & Do \\
\hline 34 & M & 54 & T3N1M0 & G2 & Do \\
\hline 35 & M & 68 & T3N1M0 & G3 & Do \\
\hline 37 & $\mathrm{M}$ & 53 & T2N1M0 & G3 & Do \\
\hline 14 & M & 69 & T3N2M0 & G3 & C \\
\hline 21 & M & 64 & T3N1M0 & G3 & C. \\
\hline 22 & M & 41 & T3N1M0 & G3 & $\mathrm{C}$ \\
\hline 30 & M & 63 & T3N2M1 & G3 & $\mathrm{C}$ \\
\hline 33 & $F$ & 73 & T3N2M0 & $\mathrm{G} 2$ & $\mathrm{C}$ \\
\hline
\end{tabular}

"Differentiation grade: $\mathrm{G} 1=$ well differentiated; $\mathrm{G} 2$ = moderately differentiated; G3 = poorly differentiated.

${ }^{b}$ Tissue sample from a lymph node metastasis. by calculating the deoxyribonucleic acid index as defined by the convention of nomenclature for deoxyribonucleic acid [13]. A diploid histogram contained a G0/G1 peak and a G2/tetraploid peak above DNA index 1.90 and below DNA index 2.10, with a G2/tetraploid fraction up to $10 \%$. G2/tetraploid fractions above $10 \%$ were considered abnormal. An aneuploid population of cells was defined as a G0/G1 population of cells that produced a discrete peak separate from the diploid population, constituting $\geq 5 \%$ of the cells in the biopsy specimens. The coefficient of variation was $\leq 6 \%$ in all cases.

\section{Cytogenetics}

Fresh tissue samples of esophageal mucosa and adenocarcinoma obtained from the resection specimens were minced with sharp scissors into pieces approximately $\leq 1$ $\mathrm{mm}$ in diameter. The pieces were incubated in Dulbecco's modified Eagles' medium (DMEM)/Ham's F12 culture medium containing $5 \mu \mathrm{g} / \mathrm{mL}$ Amphotericin B, $100 \mathrm{IU} / \mathrm{mL}$ penicillin, and $0.2 \mathrm{mg} / \mathrm{mL}$ streptomycin for $1 \mathrm{~h}$. The suspension was washed in medium, then medium containing collagenase II $(200 \mathrm{IU} / \mathrm{mL})$ was added for several hours to obtain enzymatical disaggregation of cells. The suspension was washed two times in medium and dispersed into $50-\mathrm{mL}$ cell culture T-flasks with $10 \mathrm{~mL}$ DMEM/Ham's F12 culture medium with $10 \%$ fetal calf serum, $0.3 \mathrm{mg} / \mathrm{mL}$ glutamine, $100 \mathrm{IU} / \mathrm{mL}$ penicillin, and $0.1 \mathrm{mg} / \mathrm{mL}$ streptomycin. The cultures were maintained at $37^{\circ} \mathrm{C}$ in a humidified atmo-

Table 5 Flow cytometric and cytogenetic analysis of adenocarcinoma in the distal esophagus without Barrett's mucosa

\begin{tabular}{|c|c|c|c|c|c|c|}
\hline \multirow[b]{2}{*}{$\begin{array}{l}\text { Patient } \\
\text { no. }\end{array}$} & \multirow[b]{2}{*}{$\begin{array}{l}\text { Flow cytometry } \\
\text { (DNA indices) }\end{array}$} & \multicolumn{5}{|c|}{ No. of metaphases analyzed } \\
\hline & & Total & Normal & $\begin{array}{l}\text { Abnormal } \\
\text { nonclonal }\end{array}$ & $\begin{array}{l}\text { Abnormal } \\
\text { clonal }\end{array}$ & Karyotype of clonal abnormality \\
\hline 2 & & 1 & 1 & & & \\
\hline 6 & Aneuploid (1.53) & 5 & 2 & & 3 & $45(45-64)<2 n>, X,-Y[c p 3]$ \\
\hline 7 & Aneuploid (1.65) & 21 & & & $12+9^{a}$ & 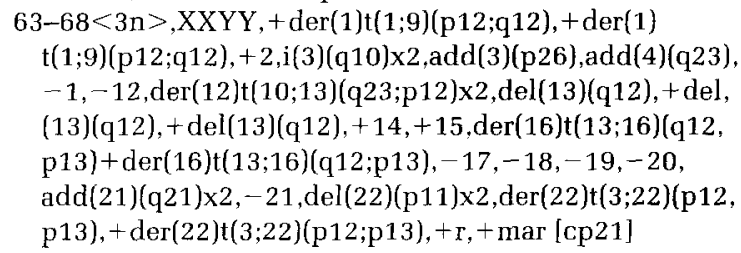 \\
\hline 8 & Diploid & 17 & 10 & 2 & 5 & $91-94<4 \mathrm{n}>, \mathrm{XXYY},+12,+18[\mathrm{cp} 5]$ \\
\hline 10 & Aneuploid $(1.56,1.94)$ & 23 & 2 & & $5+16^{a}$ & 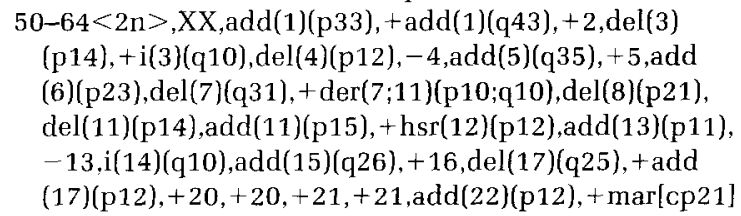 \\
\hline 16 & Aneuploid (1.69) & 32 & 19 & 2 & 11 & $\begin{array}{l}40(28-45]<2 n>, X,-Y[5],-1,-2,-4,-5,-9,-11,-13 \\
\quad-17,-18,-22[\mathrm{cp} 11]\end{array}$ \\
\hline 28 & Aneuploid (2.17) & 16 & 12 & 1 & 3 & $44-45, X,-Y[c p 3]$ \\
\hline 34 & & 8 & & & $4+4^{a}$ & $\begin{array}{l}58-60<3 \mathrm{n}>, \mathrm{XX},-\mathrm{Y}, \text { add }(1)(\mathrm{p} 11), \operatorname{del}(3)(\mathrm{p} 24),+\operatorname{del}(3) \\
\quad(\mathrm{p} 24),-4, \mathrm{i}(5)(\mathrm{p} 10),-6, \text { add(7)(p1?),add(8)(q24)x2,add } \\
\quad(9)(\mathrm{p} 21),-9, \mathrm{hsr}(11)(\mathrm{p} 14), \operatorname{del}(12)(\mathrm{q} 21),-12, \mathrm{i}(14)(\mathrm{q} 10) \\
\quad-14,-15,-17,-17,-18,-18,-18,-21,-21,+\mathrm{r} \\
\quad+4 \mathrm{mar}[\mathrm{cp} 8)\end{array}$ \\
\hline 35 & Aneuploid (1.73) & 1 & 1 & & & \\
\hline 37 & Diploid & 1 & 1 & & & \\
\hline
\end{tabular}

"Indicates metaphases that were counted, with markers identified, but which could not be completely karyotyped. 
Table 6 Flow cytometric and cytogenetic analysis of adenocarcinoma in the cardia

\begin{tabular}{|c|c|c|c|c|c|c|}
\hline \multirow[b]{2}{*}{$\begin{array}{l}\text { Patient } \\
\text { no. }\end{array}$} & \multirow[b]{2}{*}{$\begin{array}{l}\text { Flow cytometry } \\
\text { (DNA indices) }\end{array}$} & \multicolumn{5}{|r|}{ No. of metaphases analyzed } \\
\hline & & Total & Normal & $\begin{array}{l}\text { Abnormal } \\
\text { nonclonal }\end{array}$ & $\begin{array}{l}\text { Abnormal } \\
\text { clonal }\end{array}$ & Karyotype of clonal abnormality \\
\hline 14 & & 6 & 6 & & & \\
\hline 21 & Tetraploid & 1 & 1 & & & \\
\hline 22 & $\begin{array}{l}\text { Aneuploid } \\
(1.41,2.69)\end{array}$ & 1 & 1 & & & \\
\hline 30 & & 6 & 5 & 1 & & \\
\hline 33 & & 11 & 2 & & 9 & $\begin{array}{l}60-77<3 \mathrm{n}>, \mathrm{XX},-\mathrm{X},-1, \operatorname{add}(3)(\mathrm{q} 29),+\mathrm{i}(3)(\mathrm{q} 10),-4,-5, \operatorname{del}(6)(\mathrm{q} 24) \mathrm{x} 2, \\
\quad+\operatorname{add}(6)(\mathrm{p} 22), \operatorname{add}(8)(\mathrm{p} 22),-12, \operatorname{add}(13)(\mathrm{q} 34),+\operatorname{add}(13)(\mathrm{q} 34), \operatorname{add}(14) \\
(\mathrm{q} 32) \mathrm{x} 2,-14, \operatorname{add}(15)(\mathrm{p} 13),-15,+16,+16,+16,+16, \operatorname{add}(17)(\mathrm{q} 25), \\
\operatorname{del}(17)(\mathrm{q} 22),-18, \operatorname{add}(20)(\mathrm{p} 11),-20,-21,-22,+\operatorname{mar}[\operatorname{cp} 9]\end{array}$ \\
\hline
\end{tabular}

sphere of $5 \%$ carbon dioxide in air. The specimens were harvested for cytogenetic analysis after 2 or 3 days of growth in vitro (short-term culture). To synchronize the cells in the cell cycles the cultures were treated with methotrexate $(1 \mu \mathrm{g} / \mathrm{mL})$ overnight and tymidine $\left(10^{-5} \mathrm{M}\right) 6 \mathrm{~h}$ before harvesting [14]. Metaphase cells were arrested by exposure to colcemid $(0.1 \mu \mathrm{g} / \mathrm{mL})$ for $1 \mathrm{~h}$. The mitotic cells were loosened by shaking the culture flasks, washed with medium, swelled in $\mathrm{KCl} 0.075 \mathrm{M}$ at $37^{\circ} \mathrm{C}$ for $8 \mathrm{~min}$, and fixed according to standard procedures using methanol:acetic acid (3:1). The remaining monolayer was flooded with KCl-EGTA for $20 \mathrm{~min}$ and scraped out with a rubber policeman, washed with $\mathrm{KCl} 0.075 \mathrm{M}$, and processed as above. The chromosomes were identified using RFA and QFQ banding. The quality of metaphases was irregular, and not all cells could always be fully karyotyped. Karyotype designations were in accordance with the International System for Human Cytogenetic Nomenclature [15]. As a control, preoperative blood samples of the patients were obtained and cytogenetic analysis of the leucocytes was performed.

\section{RESULTS}

\section{Clinical Characteristics}

Table 1 shows the clinicai and histopathologic characteristics of 22 patients with an adenocarcinoma in Barrett's esophagus. The histologic diagnosis of the mucosal specimens on which cytogenetic and FCM analysis were performed are listed according to the mucosal type (i.e., Barrett's epithelium or squamous epithelium). In one patient (no. 19), tumor tissue for cytogenetic analysis was obtained from a lymph node metastasis, while the tissue culture of the primary tumor was not successful.

\section{Barrett's Mucosa}

The results of flowcytometric (12 cases) and cytogenetic analysis (eight cases) of Barrett's mucosa are listed in Table 2. FCM showed aneuploidy in three cases, of which clonal abnormalities were found in one (no. 25). In this patient the DNA index of Barrett's mucosa was 1.61, correlating with the modal chromosome number (near triploid) found at cytogenetic analysis. One of the diploid specimens of Barrett's mucosa showed a hypodiploid karyotype with loss of the $\mathrm{Y}$ chromosome. The number of metaphases was insufficient in four cases (fewer than five mitoses). In three patients the mucosal tissue samples that were analyzed cytogenetically contained only squamous epithelium. In these cases Barrett's mucosa seen histologically in their resection specimens was not present in the tissue samples for cytogenetic analysis. These samples all showed normal karyotypes. In 11 patients of 22 , tissue cultures of the mucosa were not successful, which prevented cytogenetic analysis.

\section{Adenocarcinoma}

Table 3 lists the data of flow cytometric and cytogenetic analysis of 22 adenocarcinomas in Barrett's esophagus. FCM showed aneuploidy in 14 cases, of which the DNA indices varied between 1.42 and 1.72 in 10 cases. Four of these 10 tumors also showed near-triploid karyotypes (nos. 19, 25, 31, and 36). Patient 13 exhibited two distinct clonal populations, one hypodiploid and another near triploid, both showing the same markers. Of the 12 cytogenetic abnormal clones identified, five were hypodiploid and two of these corresponded to near-triploid FCM indices, a situation similar to that of patient 13 . There were no

Figure 1 Histogram of flow cytometric analysis of tumor tissue of patient no. 7 .

\section{no. of events}

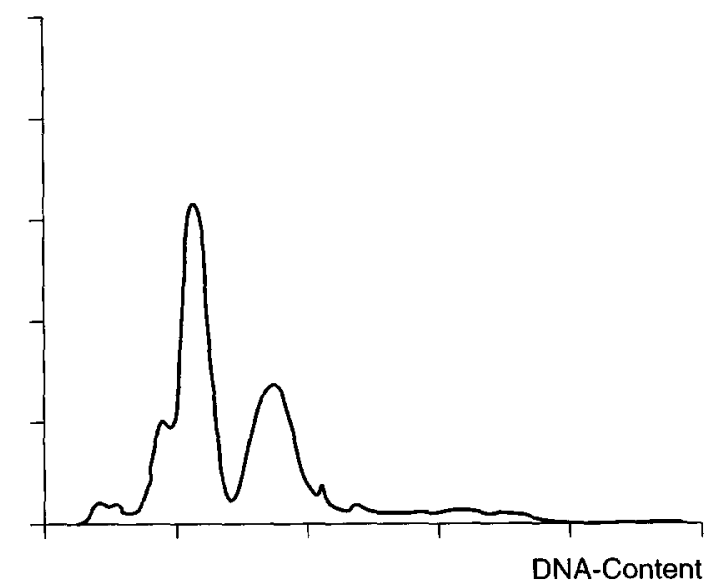




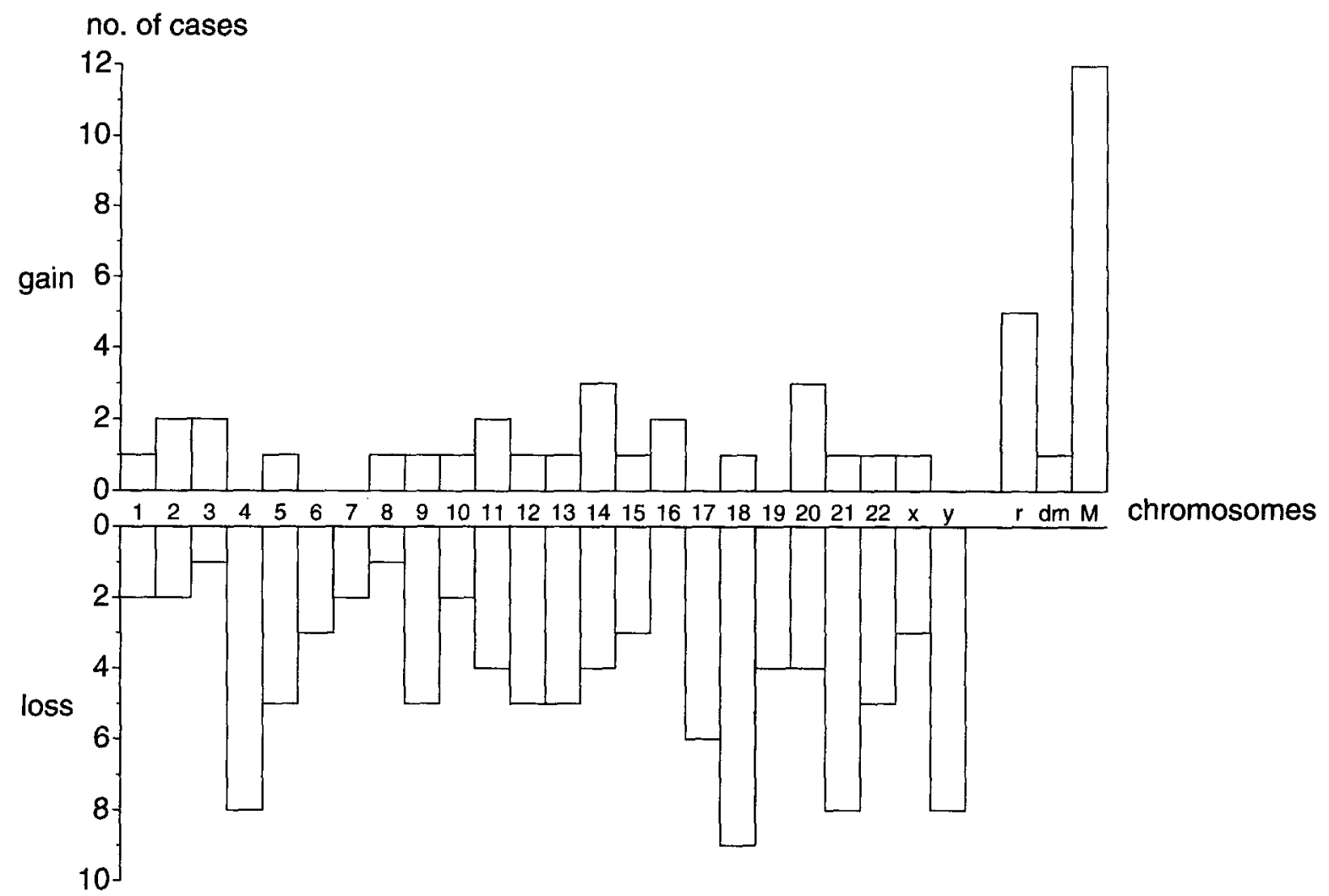

Figure 2 Histogram of all clonal numerical chromosome changes observed in tumor cells of 19 patients with an adenocarcinoma in Barrett's esophagus (11), the distal esophagus without Barrett's mucosa (7), and cardia (1). Gains and losses depicted are determined relative to ploidy. Unidentified markers are also shown. $\mathrm{r}=$ ring chromosome, $\mathrm{dm}=$ double minute, $\mathrm{mar}=$ marker chromosome.

mitoses found in one case, and an inadequate number of metaphases in four cases. In four tumors aneuploidy or tetraploidy was found by FCM, but this could not be confirmed cytogenetically.

Table 4 shows the clinical and histopathologic characteristics of the patients with an adenocarcinoma in the distal esophagus without Barrett's mucosa $(n=10)$ and cardia $(n=5)$. In two patients the tumor appeared to be irresectable at laparotomy and tumor tissue was obtained from lymph node metastases (nos. 7 and 8). All esophageal mucosa specimens were of the squamous cell type. Cytogenetic analysis of squamous epithelium was performed in six cases, and at random, numeric changes were found in four of them. In the other nine patients tissue cultures of the squamous epithelium were not successful.

The results of FCM and cytogenetic analysis of adenocarcinoma located in the distal esophagus without Barrett's mucosa and cardia are listed in Tables 5 and 6 , respectively. FCM showed aneuploidy in six of the 10 adenocarcinomas of the distal esophagus, of which the DNA index correlated with the modal chromosome number found at cytogenetic analysis in two (nos. 7 and 10) (Table 5). An FCM histogram of patient 7 showed a hypodiploid shoulder and an aneuploid peak with a DNA index of 1.65 (Fig. 1). Furthermore, three others had DNA indices varying between 1.53 and 2.17 , but hypodiploid cytogenetic clones were found (nos. 6, 16, and 28). An inadequate number of metaphases was found in three cases. FCM showed a tetraploid population in one case and aneuploidy in another case of adenocarcinoma of the cardia (Table 6). In both cases only one metaphase was analyzed and showed a normal karyotype. More than 10 metaphases were analyzed in one case, in which an abnormal clone was found. Constitutional chromosomal abnormalities were not found in any of the patients by cytogenetic analysis of peripheral blood lymphocytes.

Clonal chromosomal abnormalities in Barrett's mucosa were seen in two cases with near-diploid and near-triploid chromosome numbers, respectively. In 19 cases clonal chromosomal abnormalities were found in tumor tissue. These were analyzed for the presence of common numeric and structural aberrations. All chromosomes contributed to numeric changes. Gains and losses of chromosomes, determined relatively to ploidy, were plotted on a histogram (Fig. 2). When compared with the ploidy of individual tumors, whole chromosome losses were more common than gains. Losses of chromosomes $4,18,21$, and $\mathrm{Y}$ were the most frequent numeric losses. Loss of the $\mathrm{Y}$ was observed in eight of 13 tumors of males (62\%). Chromosomes 14 and 20 were most frequently gained. Loss of chromosome 16 was not observed. Structural abnormalities were observed in 13 of the abnormal clonal karyotypes (68\%). All 


\section{no. of cases}

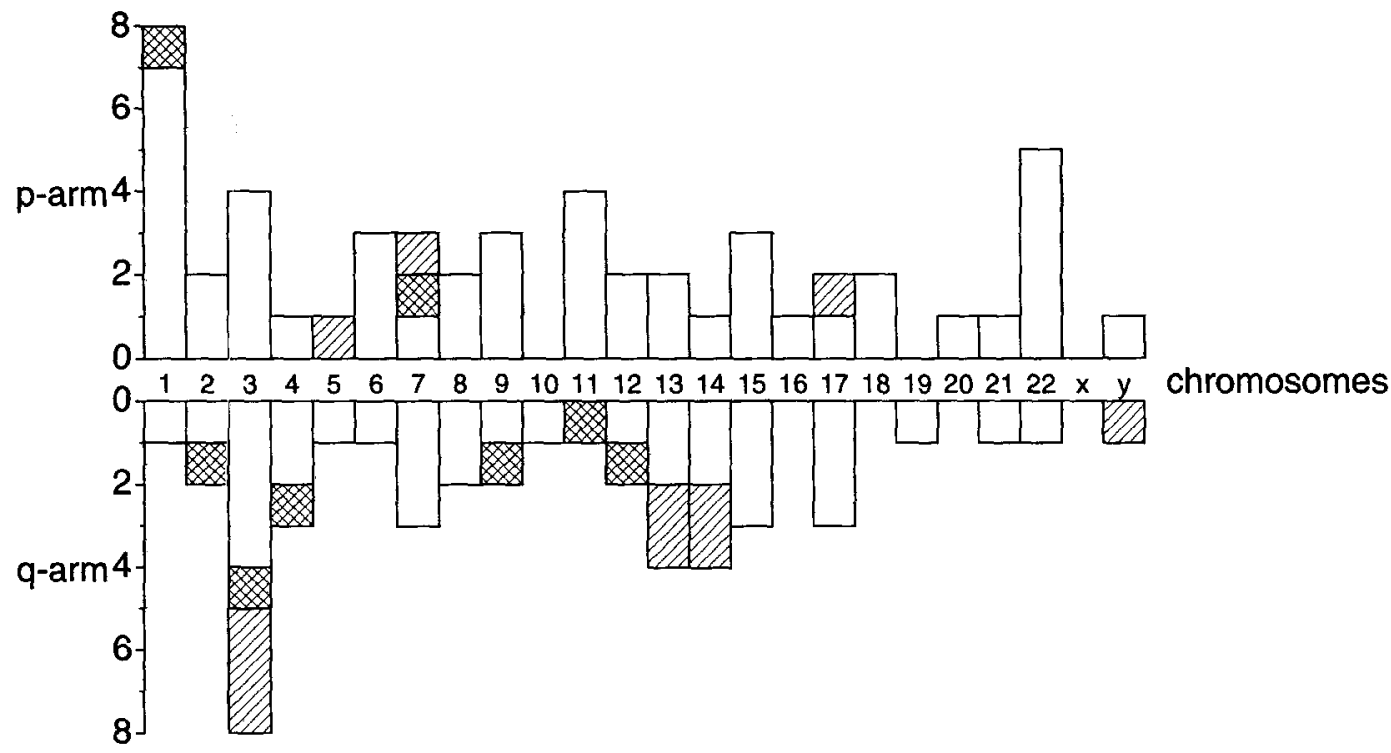

Figure 3 Histogram of all clonal structural chromosome changes observed in tumor cells of 12 patients with an adenocarcinoma in Barrett's esophagus (8), the distal esophagus without Barrett's mucosa (3), and cardia (1). Diagonal bars = isochromosomes; hatched bars, unbalanced translocations).

chromosome arms except 10p, 16q, 18q, 19p, 20q, and chromosome $X$ participated in structural changes (Fig. 3). The chromosome arms most frequently rearranged were $1 p, 3 q, 11 p$, and 22p. Abnormalities of chromosome 1p arm frequently resulted in (partial) deletion, with the shortest region of overlap at $1 \mathrm{p} 22-33$ (Fig. 4). In contrast, chromosome $11 \mathrm{p}$ and $22 \mathrm{p}$ rearrangements often showed gain of material. A homogenous staining region (hsr) of $11 \mathrm{p} 14$ was observed in three cases and gain at $11 \mathrm{p} 15$ in one case, whereas a deletion on chromosome arm 11p was seen in one case with the break point at 11p14 (Fig. 4). Structural rearrangements of chromosome arm 3q were frequently observed, including deletions in two cases, gains in two cases, an unbalanced translocation in one case, and isochromosomes in three cases (Fig. 4). The breakpoint occurred at the centromere in four cases. Several recurrent isochromosomes were identified. The most frequent were $\mathrm{i}(3 \mathrm{q})$ in three cases, $\mathrm{i}(13 \mathrm{q})$ in two cases, and $\mathrm{i}(14 \mathrm{q})$ in two cases.

\section{DISCUSSION}

In 1976 Nowell hypothesized that cancer develops in association with an acquired genetic instability that predisposes to the acquisition of abnormal clones of cells with accumulated genetic errors [16]. It has been demonstrated that neoplastic progression in Barrett's esophagus is associated with a similar process of clonal evolution $[5,6,10$, 17]. In our study we analyzed 37 adenocarcinomas of the esophagus and cardia, of which 22 arose in Barrett's esophagus. In Barrett's mucosa we found normal karyotypes, except in one case where a complex karyotype was found with the same markers and rearrangements as in the adenocarcinoma of the same patient. A theoretical possibility in this case is that the abnormal tissue obtained from the Barrett's segment that was spatially separate from the cancer contained an unidentified microscopic focus of carcinoma. A specific karyotypic change common to all cases with genetic abnormalities was not found. The absence of differences in the complex pattern of cytogenetic changes between adenocarcinomas in Barrett's esophagus, the distal esophagus without Barrett's mucosa or cardia, suggests a common pathway of origin at all three anatomic sites. This is similar to the results of others $[8,9]$. A good correlation between DNA indices of the aneuploid tumors and the modal chromosome numbers of the abnormal karyotypes was found in most of the tumors with multiple and complex chromosomal rearrangements. Recurrent combination of hypodiploid and triploid clones correspond to a pattern of clonal progression that is characterized by chromosome losses followed by secondary duplication and losses, a mechanism which has previously been described in adenocarcinoma [18]. Whereas balanced translocations were seldom found in this study, losses due to missing chromosomes or apparently unbalanced rearrangements (derivative chromosomes, deletions, and isochromosomes) were frequently observed. Marker chromosomes were common and some of the missing chromosomal material obviously resides in these unidentified chromosomes. Whole chromosome losses of 4,18 , and 21 , and in males, $\mathrm{Y}$, were the most frequent numeric changes in this series. Frequent numeric loss of chromosomes 4, 18, 21, and $Y$ has been described in colorectal carcinoma [19-22]. Loss of the $\mathrm{Y}$ chromosome has been demonstrated in different gastrointestinal malignancies [19, 20, 23] and brain tumors $[22,24]$. In Barrett's esophagus and esophageal adenocarcinoma loss of the $\mathrm{Y}$ chromosome also appears to be a 


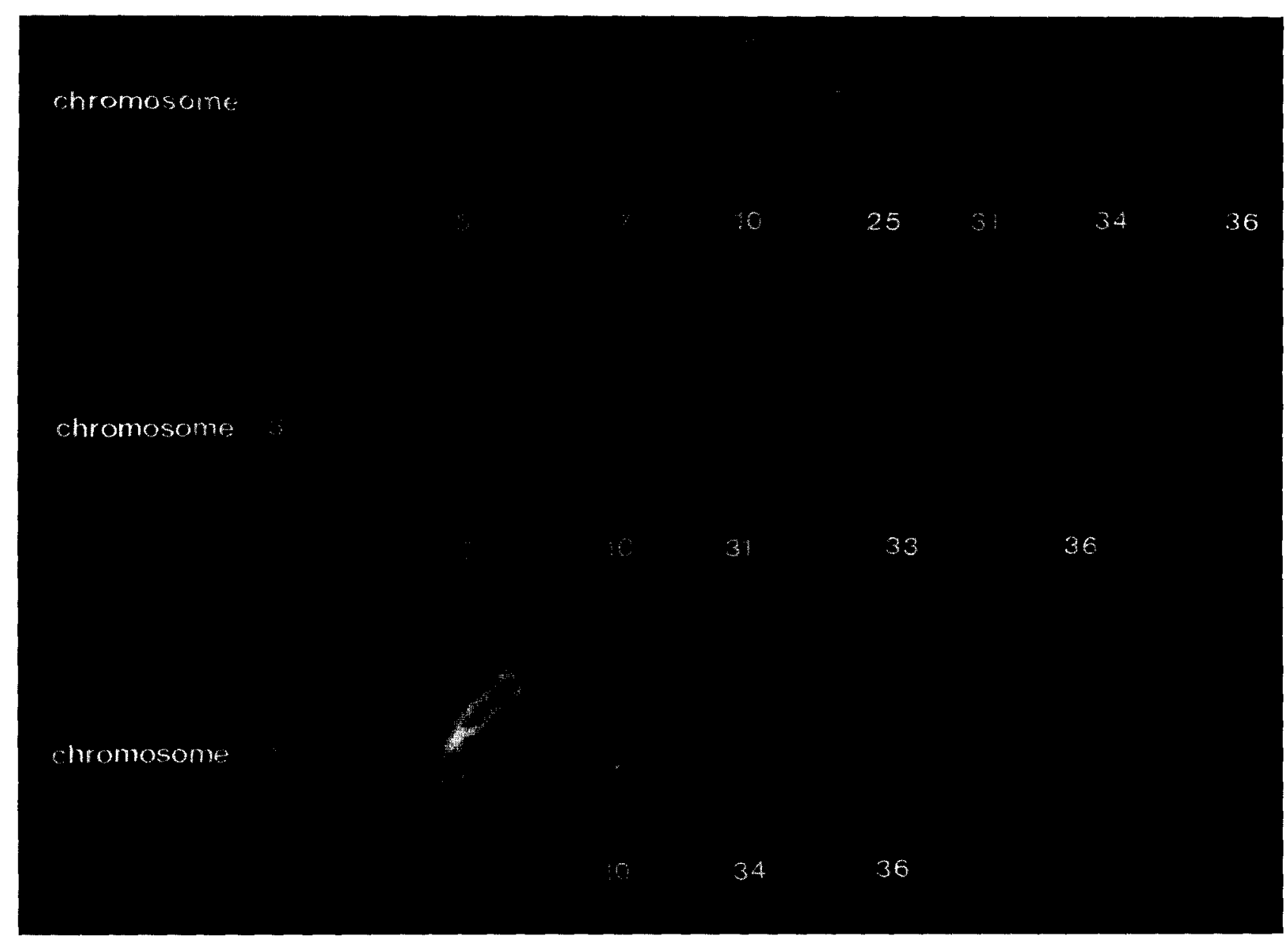

Figure 4 Examples of rearrangements affecting chromosome arms 1p, 3q, and 11p in the tumors studied. Patient numbers are indicated under the rearranged chromosomes. $R$ bands are used in the majority of cases and $Q$ bands for patient nos. 1 (chromosome 11), 5 (chromosome 1), 31 (chromosomes 1 and 3), and 36 (chromosome 3).

common occurrence $[7,8,17,25]$. It has been suggested that tissues retaining rapid cellular proliferation rates in elderly men are more prone to loss of the $\mathrm{Y}$ chromosome [26]. In our series loss of the Y chromosome in Barrett's mucosa and adenocarcinoma occurred in $62 \%$ of the male patients, but not merely the oldest ones. Furthermore, cytogenetic analysis of peripheral blood lymphocytes did not reveal $Y$ loss. Although there is a male predominance in the incidence of Barrett's esophagus and esophageal adenocarcinoma $[1,4,27]$, the significance of $Y$ loss in unclear, because there are no cancer genes linked to the $\mathrm{Y}$ chromosome so far. Recurrent gains of chromosomes 14 and 20 were seen in this series. Extra copies of chromosome 20 were also found in colorectal carcinomas $[19,22]$. Structural abnormalities of chromosome arms 1p, 3q, 11p, and $22 p$ were most frequently observed. Structural rearrangements of the short arm of chromosome 1 resulted most often in deletions, with the shortest region of overlap being 1p22-33. Frequent rearrangements of chromosome arm $1 p$ were also described in gastric and colorectal carcinomas [20, 23]. N-ras, a transforming gene from a neuroblastoma cell line, has been assigned to $1 \mathrm{p} 22-31[28,29]$.
Rao et al. described structural rearrangements of $3 q$ in six of nine gastric and esophageal adenocarcinomas [9]. Allelotype analysis in osteosarcomas suggests the existence of tumor suppressor genes on the long arm of chromosome 3 [30]. Structural rearrangements in the 11p13-15 region were found in Barrett's adenocarcinomas and other adenocarcinomas of the esophagus and stomach [8]. Genetic changes affecting the 11 p13-15 region have previously been associated with Wilm's tumor, hepatoblastoma, rhabdomyosarcoma, and carcinoma of the bladder and breast [31-33]. Furthermore, the H-ras-1 protooncogene has been localized to band 11 p15 [33]. Whether these cancer genes are implicated in the progression of oesophageal tumors should be investigated using molecular techniques.

These studies show that Barrett's mucosa and adenocarcinoma can be successfully karyotyped using banding techniques. A chromosomal abnormality common to all tumors was not identified, although hot spots for structural rearrangements have been seen in chromosomes $1 \mathrm{p}$, $3 \mathrm{q}, 11 \mathrm{p}$, and $22 \mathrm{p}$, as well as frequent losses of chromosomes $4,18,21$, and $Y$. 


\section{REFERENCES}

1. Pera M, Cameron AJ, Trastek VF, Carpenter HA, Zinsmeister $A R$ (1993): Increasing incidence of adenocarcinoma of the esophagus and esophagogástric junction. Gastroenterology 104:510-513.

2. Powell J, McConkey CL (1990): Increasing incidence of adenocarcinoma of the gastric cardia and adjacent sites. Br J Cancer 59:440-443.

3. DeMeester TR (1993): Barrett's esophagus. Surgery 113:239241

4. Williamson WA, Ellis FH, Gibb SP, et al. (1991): Barrett's esophagus: prevalence and incidence of adenocarcinoma. Arch Intern Med 151:2212--2216.

5. Rabinovitch PS, Reid BJ, Haggitt RC, Norwood TH, Rubin CE (1989): Progression to cancer in Barrett's esophagus is associated with genomic instability. Lab Invest 60:65-71.

6. Reid BJ, Blount PL, Rubin C.E, Levine DS, Haggitt RC, Rabinovitch PS (1992): Flow-cytometric and histological progression to malignancy in Barrett's esophagus: prospective endoscopic surveillance of a cohort. Gastroenterology 102:1212-1219.

7. Garewal HS, Sampliner R, Liu Y, Trent JM (1989): Chromosomal rearrangements in Barrett's esophagus. A premalignant lesion of esophageal adenocarcinoma. Cancer Genet Cytogenet 42:281-296.

8. Rodriguez E, Rao PH, Ladanyi M, Altorki N, Albino AP, Kelsen DP, Jahnwar SC, Chaganti RSK (1990): 11p13-15 is a specific region of chromosomal rearrangement in gastric and esophageal adenocarcinomas. Cancer Res 50:6410-6416.

9. Rao PH, Mathew S, Kelser. DP, Chaganti RSK (1995): Cytogenetics of gastric and esophageal adenocarcinomas. $3 \mathrm{q}$ deletion as a possible primary chromosomal change. Cancer Genet Cytogenet 81:139-143.

10. Raskind WH, Norwood 'T', Levine DS, Haggitt RC, Rabinovitch PS, Reid BJ (1992): Persistent clonal areas and clonal expansion in Barrett's esophagus. Cancer Res 52:2946-2950.

11. Morson BC, Sobin LH, Grundmann E, Johansen A, Nagayo T, Serck-Hanssen A (1980): Precancerous conditions and epithelial dysplasia in the stcmach. J Clin Pathol 33:711-721.

12. Vindelov LL, Christensen IJ, Nissen NI (1983): A detergenttrypsin method for the pieparation of nuclei for flow cytometric DNA analysis. Cytometry 3:323-327.

13. Hiddeman $W$, Sluman J, Andreeff $M$, Barlogie B, Herman CH), Leif RC, Mayall BH, Murphy RF, Sandberg AA (1984): Special report. Convention on nomenclature for DNA-cytometry. Cytometry 5:445-446.

14. Hagemeijer A, Smit EME, Bootsma D (1979): Improved identification of chromosomes of leucemic cells in methotrexate treated cultures. Cytogenet Cell Genet 23:208-212.

15. ISCN (1991): Guidelines for Cancer Cytogenetics: supplement to an International System for Human Cytogenetic Nomenclature. F Mitelman, ed. S. Karger, Basel.

16. Nowell PC (1976): The clonal evolution of tumor cell populations. Science 194:23-28.

17. Krishnadath KK, Tilanus HW, van Blankenstein M, Hop WCJ, Teygeman R, Mulder AH, Bosman FT, van Dekken H (1995): A cumulation of genetic abnormalities during neoplastic progression in Barrett's esophagus. Cancer Res 55:1971-1976.
18. Remvikos $\mathrm{Y}$, Muleris M, Vielh PH, Salmon RJ, Dutrillaux B (1988): DNA content and genetic evolution of human colorectal adenocarcinoma. A study by flow cytometry and cytogenetic analysis. Int $J$ Cancer 42:539-543.

19. Bardi G, Johansson B, Pandis N, Mandahl N, Bak-Jensen E, Fenger C (1994): Cytogenetic findings in 152 colorectal adenocarcinomas-correlation with clinicopathologic features. 4th European workshop on cytogenetics and molecular genetics of human solid tumors. (Äbstr.).

20. Xiao S, Wei W, Feng XL, Shi YH, Liu QZ, Li P (1992): Direct chromosome analysis of seven primary colorectal carcinomas. Cancer Genet Cytogenet 62:32-39.

21. Muleris M, Salmon RJ, Dutrillaux B (1990): Cytogenetics of colorectal adenocarcinoma. Cancer Genet Cytogenet 46:143156.

22. Mitelman F (1990): Catalogue of Chromosome Aberrations in Cancer. 3rd ed. Alan R. Liss, New York.

23. Ochi H, Douglass HO, Sandberg A (1986): Cytogenetic studies in primary gastric cancer. Cancer Genet Cytogenet 22: 295-307.

24. Bigner SH, Mark J, Bullard DE, Mahaley MS, Bigner DD (1986): Chromosomal evolution in malignant human gliomas starts with specific and usually numerical deviations. Cancer Genet Cytogenet 22:121-135.

25. Hunter S, Gramlich T, Abbott K, Varma VY (1993): Chromosome loss in esophageal carcinoma; an in situ hybridization study. Genes Chrom Cancer 8:172-177.

26. Pierre RV, Hoagland HC (1972): Age associated aneuploidy: Loss of Y-chromosome from human bone marrow cells with aging. Cancer 30:889-894.

27. Menke-Pluymers MBE, Hop WCJ, Dees J, van Blankenstein M, Tilanus HW (1993): Risk factors for the development of an adenocarcinoma in columnar-lined (Barrett) esophagus. Cancer 72:1155-1158

28. de Martinville B, Cunningham IM, Murray MJ, Francke U (1984): The N-ras oncogene assigned to chromosome 1 (p31 $\rightarrow$ cen) by somatic cell hybrid analysis. Cytogenet Cell Genet 37:531.

29. Davis M, Malcolm S, Hall A (1984): The N-ras oncogene is located on the short arm of chromosome 1. Cytogenet Cell Genet 37:448.

30. Yamaguchi T, Toguchida J, Yamamura T, Kotoura Y, Takada N, Kawaguchi N, Kaneko Y, Nakamura Y, Sasaki MS, Ishizaki $K$ (1993): Allelotype analysis in osteosarcomas: frequent allele loss on 3q,13q, 17p and 18q. Cancer Res 52:2419-2423.

31. Fearon ER, Feinberg AP, Hamilton SH, Vogelstein B (1985): Loss of genes on the short arm of chromosome 11 in bladder cancer. Nature (London) 318:377-380.

32. Theillet C, Lidereau R, Escot C, Hutzell P, Brunet M, Gest J, Schlom J, Callahan R (1986): Loss of a c-H-ras-1 allele and aggressive human primary breast carcinomas. Cancer Res 46:4776-4781.

33. Popescu NC, Amsbaugh SC, Di Paolo JA, Tronick SR, Aaronson SA, Swan DC (1985): Chromosomal localization of three human ras genes by in situ molecular hybridization. Somat Cell Mol Genet 11:149-155. 